\title{
Repair of chromosome and DNA breaks versus cell survival in
}

\section{Chinese hamster cells}

\author{
J. BUSSINK†, P. J. TOFILON and W. A. BROCK* \\ (Received 1 September 1995; revision received 13 February 1996; accepted 27 February 1996)
}

\begin{abstract}
Clonogenic and non-clonogenic parameters of cell survival were compared in irradiated Chinese hamster cells. Clonogenic survival, chromatid break and repair kinetics, as well as DNA damage and repair, were assessed in synchronized cells in different parts of the cell cycle. $\mathrm{G}_{2}$ chromatid damage and repair was examined in metaphase chromosomes of cells irradiated during $\mathrm{S}$ and $\mathrm{G}_{2}$ phase, treated with or without inhibitors of DNA repair. Bromodeoxyuridine labelling of S phase cells starting at the time of irradiation made it possible to determine precisely, while scoring metaphase chromosomes, whether cells were irradiated in mid $S$, late $S$, or $G_{2}$ phases of the cycle. The results showed that chromatid breaks induced in $\mathrm{S}$ phase are efficiently repaired until the moment cells progress into $G_{2}$, when repair stops abruptly. Chromatid damage in $\mathrm{G}_{2}$ phase is not repaired. On the other hand, DNA double-strand breaks are repaired in all phases of the cycle, even during $G_{2}$ phase which has no concurrent chromatid break repair. Finally, there is no consistent correlation between chromatid damage and repair, DNA damage and repair, and cell survival, thus indicating that the interaction of different parameters of radiosensitivity must be better understood for them to be useful predictors of cell survival.
\end{abstract}

\section{Introduction}

Assessing the radiosensitivity of cells by clonogenic survival assay provides a direct measure of the fraction of cells capable of forming macrocolonies after a given dose of radiation. Clonogenic assays, therefore, have the advantage of being both relevant and relatively free from artifacts. However, clonogenic assays are not feasible if cells fail to proliferate in culture as distinct colonies, if they have very low cloning efficiencies, or, as is the case in primary and early passage cultures, the cell population is heterogeneous. Clonogenic assays also fail to identify specific

*Author for correspondence.

†Current address: Academisch Ziekenhuis Nijmegen, Institute of Radiotherapy, PO Box 9101, 6500 HB Nijmegen, The Netherlands.

Department of Experimental Radiotherapy, The University of Texas, M. D. Anderson Cancer Center, 1515 Holcombe Blvd., Houston, TX 77030, USA. mechanisms that account for radiosensitivity differences between different cell populations. As a result, the development of alternative, mechanism-based assays of radiosensitivity has been proposed and tested. Such assays are usually based upon known mechanisms of radiation cell killing, including radiation induced chromosome aberrations (Dewey et al. 1971, Carrano 1973), micronuclei formation (Midander and Revesz 1980), DNA damage and repair (Kelland et al. 1988, Schwartz et al. 1988, Blocher et al. 1991, Cassoni et al. 1992, Giaccia et al. 1992, Smeets et al. 1993), apoptosis (Fisher 1994), cell cycle phenomena ( $\mathrm{Su}$ and Little 1993, McIlwrath et al. 1994), or repair mechanisms (Elkind 1985, Ward 1986, Kelland et al. 1987, Iliakis et al. 1988, Schwartz et al. 1988). The accuracy of non-clonogenic assays, relative to clonogenic ones, depends upon the cell types and mechanisms assessed. Unless those specific features that happen to distinguish the radiosensitivity differences of the cells being compared are measured, there will be no correlation with clonogenic survival. Thus, a chromosome break assay would be expected to reveal radiosensitivity differences between two normal diploid fibroblast strains, since normal fibroblasts typically die by reproductive death. On the other hand, chromosome break assays would not accurately detect radiosensitivity differences between cell lines that have variable levels of radiation-induced apoptosis, because the apoptotic mechanism would destroy chromosomes in lethally irradiated cells before they could be scored. Nevertheless, apoptosis is not typical of many established cell lines (Radford 1991) and the induction and repair of chromosome damage has become a very useful and accurate method to determine radiosensitivity (Joshi et al. 1982). And, since chromosome lesions depend upon the induction of DNA strand breaks, assays of DNA damage and repair have also been considered relevant. However, assays of DNA damage have generally lacked the necessary sensitivity to detect the one or more residual double-strand breaks 
that constitute a lethal lesion (Smeets et al. 1993). Therefore, superlethal doses of radiation are used and it is assumed that the relative number of breaks measured is proportional to what would occur after small doses. Attempts to find alternatives for measuring clonogenic survival, therefore, have not yet identified a generally useful approach, and ultimate success must take into account the mechanistic determinates of radiosensitivity and their interactions.

To explore further in detail the relationship between clonogenic and non-clonogenic parameters of radiation sensitivity, we compared measurements of cell survival, chromosome aberrations, and DNA damage and repair in Chinese hamster ovary cells (CHO AA8), with a particular emphasis on $\mathrm{G}_{2}$ phase chromatid damage and repair. CHO cells were synchronized by aphidicolin block and centrifugal elutriation, and assayed for survival, chromosome aberrations, and the induction and repair of DNA doublestrand breaks. The results show that while chromatid aberrations generally correlate with survival, the repair kinetics of those breaks can be misleading. The number of DNA doublestrand breaks induced and their repair kinetics do not correlate with either survival or chromatid breaks. In fact, DNA strand break repair can be efficient, even in cells that do not repair chromatid breaks.

\section{Materials and methods}

\subsection{Cell culture}

Chinese hamster ovary cells (CHO-AA8) were grown in Hsu's modification of McCoy's 5A medium, supplemented with $15 \%$ foetal calf serum and $2 \mathrm{~mm}$ L-glutamine (Sigma Chemical Co., St Louis, MO, USA). Cultures for chromatid break determinations were seeded at a density of $8.0 \times 10^{5}$ cells in $25-\mathrm{cm}^{2}$ flasks 2 days prior to the experiment, in order to assure exponentially growing populations.

\subsection{Irradiation for chromatid break and cell survival determinations}

Cultures were irradiated with a ${ }^{137} \mathrm{Cs}$ source at a dose-rate of $2 \cdot 08 \mathrm{~Gy} / \mathrm{m}$ in. For the chromatid break experiments, cells were irradiated at $37^{\circ} \mathrm{C}$. For survival assays, synchronized cells were irradiated on ice.

\subsection{Repair inhibition}

Chromatid break repair was inhibited by the addition of 9- $\beta$-D-arabinofuranosyl-2-fluoroadenine (F-ara-A) to a final concentration of $200 \mu \mathrm{M} 30 \mathrm{~min}$ prior to irradiation (Jayan th and Hittelman 1991).

\subsection{S phase labelling}

S phase cells were labelled with $1.0 \mu \mathrm{m}$ bromodeoxyuridine (BrdUrd; Sigma), added immediately after irradiation (Terry et al. 1991). The BrdUrd labelling was continuous until mitotic cells were collected.

\subsection{Preparation of metaphases}

Mitotic cells were collected at different times after irradiation $(90,120,150,180$ and $210 \mathrm{~min})$ by incubating them for $1 \mathrm{~h}$ with $0.05 \mu \mathrm{g} / \mathrm{ml}$ colcemid (GIBCO, Long Island, NY, USA), followed by vigorous shaking. As a control, the cells remaining after shake-off were collected by trypsinization and found to contain the same level of chromatid damage as the cells selected by shake-off alone. After shake-off, the cells were centrifuged $(5 \mathrm{~min}$ at $200 \mathrm{~g}$ ), resuspended in $1 \%$ sodium citrate for $10 \mathrm{~min}$ at room temperature, and centrifuged again. The wet pellet was next fixed by gentle resuspension in $3 \mathrm{ml}$ Carnoy's fixative (methanol: acetic acid; $3: 1$ ). Fixation was repeated with three additional Carnoy's washes before the fixed cell suspension was dropped onto wet microscope slides. The slides were allowed to air dry overnight before staining.

\subsection{Immunocytochemical staining}

Cells were firmly attached to the microscope slides by heating in a dry oven for $30 \mathrm{~min}$ at $110^{\circ} \mathrm{C}$. The DNA was partially denatured in $4 \mathrm{NHCl}$ for $20 \mathrm{~min}$, followed by two rinses in $0 \cdot 1 \mathrm{~m}$ sodium tetraborate and a 5 -min rinse with phosphate-buffered saline (PBS). The slides were flooded with a 1:2000 dilution of IU-4 (mouse antiIdUrd/BrdUrd; Caltag Laboratories, South San Francisco, CA, USA) in PBS with $1 \%$ bovine serum albumin and $0.5 \%$ Tween-20, and then incubated for $60 \mathrm{~min}$ at $37^{\circ} \mathrm{C}$. After three 5-min rinses in PBS the slides were incubated with biotinylated anti-mouse $\operatorname{IgG}$ for $30 \mathrm{~min}$ at $37^{\circ} \mathrm{C}$. 
followed by three PBS rinses. Next, the slides were incubated with the avidin-biotin peroxidase complex (Vector Laboratories, Burlingame, CA, USA) for $30 \mathrm{~min}$ at room temperature, followed by three PBS rinses. They were next treated with $1 \%$ diaminobenzidine tetrahydrochloride and $0.03 \% \quad \mathrm{H}_{2} \mathrm{O}_{2}$ in PBS. Finally, the slides were couterstained for $10 \mathrm{~min}$ with filtered Giemsa at pH 10.

\subsection{Cell synchrony}

Synchronized CHO cell cultures were prepared by different combinations of aphidicolin block of cells released from confluent cultures, cell cycle progression after release from aphidicolin, centrifugal elutriation, and mitotic shake-off. The details of the techniques for the variou s cellcycle phases are described elsewhere (Meistrich 1977, Meistrich et al. 1977, Bussink et al. 1995). The cell cycle distribution of each population was determined by multiple-parameter flow cytometry, using DNA content and BrdUrd incorporation (Terry et al. 1991).

\subsection{Clonogenic survival}

Cell survival was determined by clonogenic assay. Colonies were stained with crystal violet after 8 days in culture and the dishes were coded and scored blindly. Data were computer fit using a linear-quadratic model.

\subsection{DNA damage}

DNA double strand break repair kinetics was measured by pulsed-field gel electrophoresis (PFGE) according to a previously published protocol (Bill et al. 1992). Briefly, the cells are irradiated in suspension to a total dose of $40 \mathrm{~Gy}$ using a ${ }^{137} \mathrm{C}$ s source with a dose-rate of $40 \mathrm{~Gy} / \mathrm{min}$. After irradiation, the cells were incubated in spinner flasks at $37^{\circ} \mathrm{C}$. At different times after irradiation, aliquots of cells were removed from the incubator, washed with $\mathrm{PBS}$ at $4^{\circ} \mathrm{C}$, and $0.5 \%$ agarose plugs, containing $2 \times 10^{5}$ cells $/ \mathrm{ml}$, were prepared by mixing equal volumes of the cell suspension and $1 \%$ low melting-point agarose (InCert; FMC Corp., Rockland, ME, USA). The plugs were allowed to gel at $4^{\circ} \mathrm{C}$ and then placed into lysis buffer $(500 \mathrm{~mm}$ EDTA, $2 \%$ Sarkosyl, $1 \mathrm{mg} / \mathrm{ml}$ proteinase-K, pH 9.0) at $50^{\circ} \mathrm{C}$ for $16 \mathrm{~h}$, followed by five 90-min washes in PBS. The plugs were placed into a $0.5 \%$ agarose gel in $0.5 \times \mathrm{TBE}(45 \mathrm{mM}$ Tris, $45 \mathrm{~mm}$ boric acid, $2 \mathrm{~mm}$ EDTA, pH 8.3; TBE). Contour clamped homogeneous electric field gel electrophoresis was performed using a continually circulating running buffer of $0.5 \times \mathrm{TBE}$ at $25^{\circ} \mathrm{C}$. The gel was run at $40 \mathrm{~V}$ for $18 \mathrm{~h}$, using a switching interval of $75 \mathrm{~min}$. The hexagonal array of electrodes allows for the current to be alternated at $120^{\circ}$. After electrophoresis, the gel was stained with ethidium bromide $(0 \cdot 1 \mu \mathrm{g} / \mathrm{ml})$ and the total DNA remaining in each plug versus DNA that migrated out and was determined by scintillation counting. The percentage of total DNA migrating from each plug relative to controls was taken as the percentage of DNA damage remaining.

\subsection{Chromatid breaks}

Chromatid breaks were scored according to the criteria of T.C. Hsu (personal communication). Briefly, chromatid damage is considered to be a break if the size of the gap is greater than the width of the chromatid or if there is misalignment or displacement of the chromatid axis across a gap. Slides were coded and scored blind.

\section{Results}

\subsection{Chromosome damage and repair in late $S$ and $G_{2}$ phase cells}

Chromatid break repair kinetics was determined in metaphase chromosomes at various times after irradiation. Cultures were irradiated, incubated for at least $30 \mathrm{~min}$ to allow mitotic cells to pass through metaphase, and colcemid blocked for an additional $60 \mathrm{~min}$. Therefore, at least $90 \mathrm{~min}$ elapsed between the time of irradiation and the first time point. Thus, the level of damage at $90 \mathrm{~min}$ was a function of the number of induced breaks and the degree of repair over a 90-min period. Therefore, to assess the number of initial breaks induced by $1.0 \mathrm{~Gy}$ at time zero, F-ara-A was added at a concentration known to inhibit chromosome break repair in these cells (Jayanth and Hittelman 1991). Figure 1 shows that $1 \cdot 0 \mathrm{~Gy}$ resulted in $2 \cdot 5$ chromatid breaks per cell remaining $90 \mathrm{~min}$ after irradiation with little or no repair observed up to $120 \mathrm{~min}$. From 120 to $210 \mathrm{~min}$, the number of chromatid breaks decreased linearlv. 


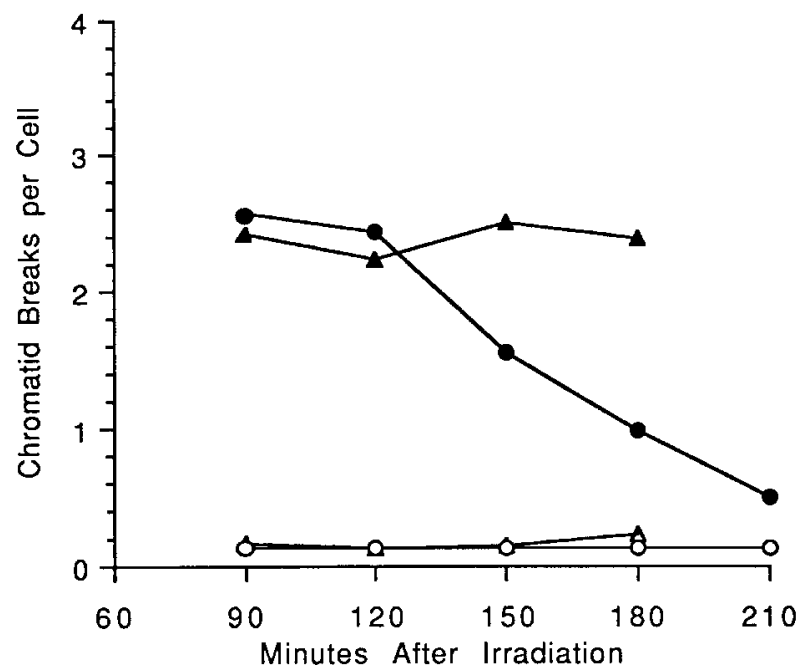

Figure 1. Chromatid break frequencies in metaphase cells at various times after $1.0 \mathrm{~Gy}$, with or without repair in hibition by $200 \mu \mathrm{M}$ F-ara-A, added $30 \mathrm{~min}$ prior to irradiation. $O$, Untreated cells; $\triangle$, F-ara-A only; $\bullet$, $1 \cdot 0$ Gy only; $\boldsymbol{\Delta}$, F-ara-A + 1.0 Gy.

returning to near control levels by $210 \mathrm{~min}$. F-araA-treated cultures showed the same number of chromatid breaks at $90 \mathrm{~min}$, but the level stayed constant through $180 \mathrm{~min}$, indicating that chromosome break repair had been blocked. Assuming that repair was inhibited from time zero, extrapolation of the F-ara-A curve to the ordinate can be taken as an estimate of the initial chromatid breaks induced by $1.0 \mathrm{~Gy}$, approximately 2.5 breaks/metaphase. If this is true, the irradiated cells without repair inhibition did not repair chromatid breaks until $2 \mathrm{~h}$ after irradiation. Initially, this was viewed as a potential example of an induced or adaptive repair mechanism, but it was also possible that $\mathrm{G}_{2}$ phase cells did not repair chromatid breaks and that the linear decline in break frequency after $2 \mathrm{~h}$ was due to the progression of repair competent $\mathrm{S}$ phase cells to metaphase.

\subsection{Progression kinetics of $S$ and $G_{2}$ phase cells to metaphase}

To determine the cell cycle position of individual metaphase cells at the time they were treated, BrdUrd was used to label $\mathrm{S}$ phase cells. The presence or absence of BrdUrd staining in metaphase chromosomes thus distinguished between metaphases treated in $S$ versus $G_{2}$ phase of the cycle. In fact, by estimating the fraction of chromosome surface area positive for BrdUrd, metaphases were identified as having been treated in early $\mathrm{S}$, mid $\mathrm{S}$, or late $\mathrm{S}$ phase. The histogram shown in Figure 2a is the result of this approach with unirradiated cells. The histogram shows the distribution of metaphases in which BrdUrd was added in $\mathrm{G}_{2}\left(0 \%\right.$ labelled), $\mathrm{S} / \mathrm{G}_{2}$ border (minimal label), mid-to-late $\mathrm{S}(5-50 \%)$, and early-to-mid $\mathrm{S}$ $(50-100 \%)$. Ninety $\min$ after BrdUrd addition, $85 \%$ of the metaphases were unlabelled, indicating that they were in $\mathrm{G}_{2}$ at the time of BrdUrd addition; the remaining cells were in late $S$. The later time points show a progressive decrease in $G_{2}$ cells with corresponding increases in earlier and earlier S phase, that is, increasing BrdUrd staining.
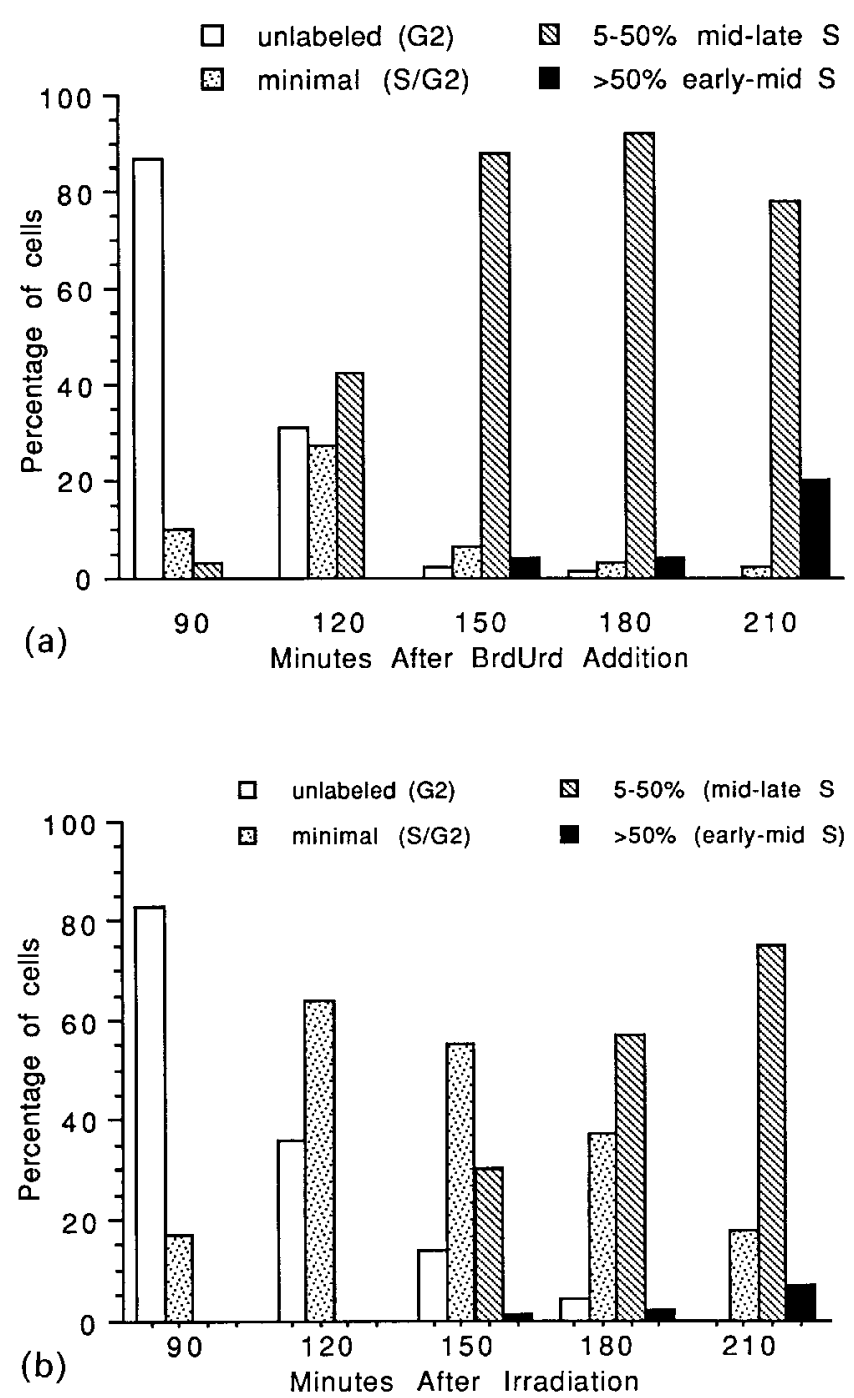

Figure 2. Degree of BrdUrd staining in metaphase chromosomes at various times after the addition of $1.0 \mu \mathrm{M}$ BrdUrd. The degree of BrdUrd staining indicates the position of the cell cycle at the time of BrdUrd addition. (a) Unirradiated cultures; (b) cultures irradiated with $1.0 \mathrm{~Gy}$ followed by immediate addition of BrdUrd. 
Figure $2 \mathrm{~b}$ shows the result from cultures irradiated immediately prior to BrdUrd addition. BrdUrd label was added after irradiation in order to avoid its sensitizing effects. As expected, the progression of cells from $G_{2}$ and $S$ phase was somewhat slower, due to radiation induced cell cycle delays. In contrast to unirradiated cultures, the only $\mathrm{S}$ phase cells that had progressed to metaphase, 90 to $120 \mathrm{~min}$ after irradiation, were labelled minimally, indicating that they were in the very final minutes or seconds of $S$ phase at the time of treatment. After $120 \mathrm{~m}$ in a similar progression of increasing numbers of $\mathrm{S}$ phase cells appeared in metaphase. This labelling method thus provides a means to determine, on an individual cell basis, the cell cycle status of each metaphase at the time it was irradiated.

\subsection{Chromatid break repair kinetics in $S$ and $G_{2}$ phase cells}

Using the approach just described, cultures were treated with $1 \cdot 0$ Gy followed by immediate BrdUrd addition. The cells were allowed to progress for various times and each metaphase was assessed for both BrdUrd incorporation and the number of chromatid breaks remaining. The results are shown in Figure 3. The top curve shows that the

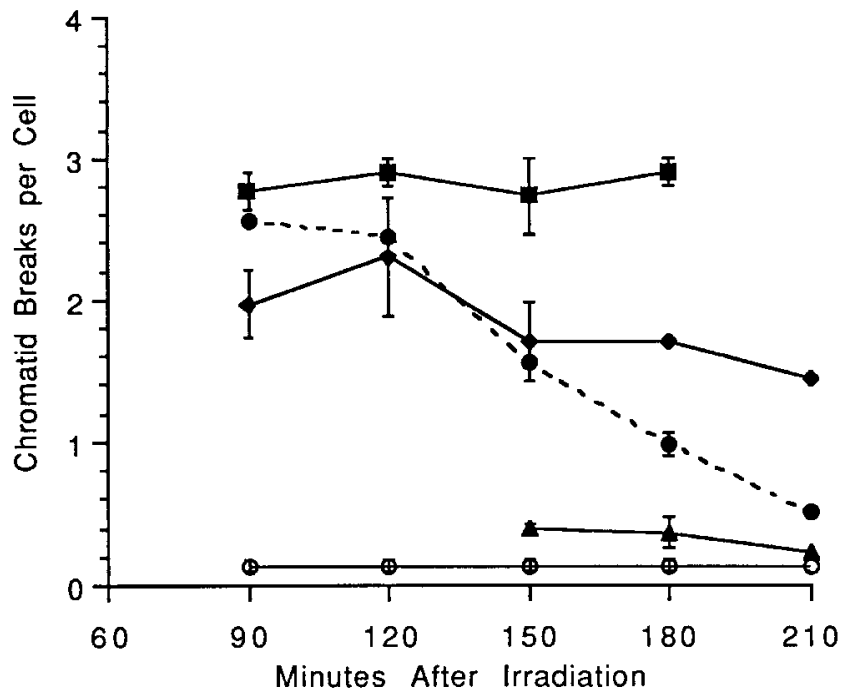

Figure 3. Chromatid break frequencies in metaphase cells at various times after $1.0 \mathrm{~Gy}$, scored as a function of the degree of BrdUrd labeling to indicate the cell cycle phase of each metaphase at the time of treatment. $O$, Untreated controls; $\square, G_{2}$ phase cells, BrdUrd negative; $\diamond, \mathrm{S}_{-} \mathrm{G}_{2}$ boundary cells, minimal BrdUrd staining; $\boldsymbol{\Delta}, \mathrm{S}$ phase cells, BrdUrd positive; $\bullet$, all cells combined at each time point. The numerical data for this figure are given in Table 1 . number of chromatid breaks induced in $\mathrm{G}_{2}$ cells does not change between 90 and 180 min after irradiation, clearly indicating that $\mathrm{G}_{2}$ cells do not repair radiation induced chromatid breaks. There are no data for $\mathrm{G}_{2}$ cells at $210 \mathrm{~min}$ because all $\mathrm{G}_{2}$ cells would have passed through metaphase before the addition of colcemid. On the other hand, cells with positive BrdUrd labelling show almost complete repair of chromosome damage by $150 \mathrm{~min}$. It is not certain if the repair occurred only in $S$ phase, before these cells entered $\mathrm{G}_{2}$, or if, in contrast to irradiated $\mathrm{G}_{2}$ cells, they were able to continue repairing breaks after entering $G_{2}$. However, the metaphases with minimal BrdUrd labelling suggest that repair capability ends abruptly as cells enter $\mathrm{G}_{2}$. These cells were at the $\mathrm{S} / \mathrm{G}_{2}$ border at the time of irradiation, having only minutes or seconds remaining before entry into $G_{2}$. The number of breaks at $90 \mathrm{~min}$ (approximately two breaks/cell) is reduced relative to the $G_{2}$ cells, but the level of these breaks remains relatively constant up to $210 \mathrm{~min}$. It thus appears that these cells repaired some chromatid breaks during the last moments of S phase but, since there is essentially no change in the number of breaks over the remaining time, the repair process must have disappeared as these cells entered $G_{2}$. These experiments clearly show an efficient repair mechanism throughout $\mathrm{S}$ phase that does not exist in $\mathrm{G}_{2}$.

The data plotted in Figure 3 are given in Table 1, which lists the number of chromatid breaks and the number of metaphases scored at each time point. Because of progression through the cell cycle, the number of metaphases representing different parts of $S$ and $G_{2}$ will be variable over time. For example, cells in mid-S at the time of treatment did not reach metaphase before $120 \mathrm{~min}$, while $\mathrm{G}_{2}$ cells were decreasing in numbers after $90 \mathrm{~min}$, due to the short duration of $\mathrm{G}_{2}$. Therefore, it was not possible to score 50-100 metaphases for each data point, which is usually considered to be ideal.

To determine if the lack of a repair capability is related to pre-versus post-replicated chromosome regions, chromatid breaks in irradiated, BrdUrd labeled, and late $S$ phase cells, were classified as being within BrdUrd positive versus negative regions. It was assumed that the majority of BrdUrd negative areas contain post-replication DNA. By estimating the fraction of chromosome areas positive for BrdUrd and the number of breaks in each region, it was determined that the probability of a break occurring in replicated versus unreplicated areas is apnroximatelv enual 
Table 1. Degree of BrdUrd labelling and the number of chromatid breaks per cell in metaphase chromosomes at various times after treatment with $1 \cdot 0 \mathrm{~Gy}$

\begin{tabular}{|c|c|c|c|c|c|}
\hline \multirow{2}{*}{$\begin{array}{l}\text { BrdUrd } \\
\text { labelling* }\end{array}$} & \multicolumn{5}{|c|}{$\begin{array}{l}\text { Chromatid breaks/cell } \pm \mathrm{SE} \\
(\mathrm{m} \text { in after irradiation })\end{array}$} \\
\hline & 90 & 120 & 150 & 180 & 210 \\
\hline $\mathrm{G}_{2}$ & $2 \cdot 77 \pm 0 \cdot 13$ & $2 \cdot 90 \pm 0 \cdot 10$ & $2 \cdot 73 \pm 0 \cdot 27$ & $2 \cdot 90 \pm 0 \cdot 10$ & \\
\hline $0 \%$ & $n=66$ & $n=34$ & $n=25$ & $n=5$ & $n=0$ \\
\hline $\mathrm{S} / \mathrm{G}_{2}$ & $1 \cdot 97 \pm 0 \cdot 17$ & $2 \cdot 30 \pm 0 \cdot 30$ & $1 \cdot 70 \pm 0 \cdot 20$ & $1 \cdot 70 \pm 0 \cdot 10$ & $1 \cdot 44 \pm 0 \cdot 10$ \\
\hline$<5 \%$ & $n=12$ & $n=44$ & $n=60$ & $n=47$ & $n=18$ \\
\hline early-late S & & & $0 \cdot 39 \pm 0 \cdot 10$ & $0 \cdot 36 \pm 0 \cdot 11$ & $0 \cdot 23 \pm 0 \cdot 10$ \\
\hline $5-100 \%$ & $n=0$ & $n=0$ & $n=51$ & $n=127$ & $n=83$ \\
\hline All cells & $\begin{array}{c}2 \cdot 56 \pm 0 \cdot 10 \\
n=78\end{array}$ & $\begin{array}{c}2 \cdot 44 \pm 0 \cdot 10 \\
n=78\end{array}$ & $\begin{array}{c}1 \cdot 55 \pm 0 \cdot 10 \\
n=136\end{array}$ & $\begin{array}{c}0 \cdot 98 \pm 0 \cdot 10 \\
n=179\end{array}$ & $\begin{array}{c}0 \cdot 50 \pm 0 \cdot 10 \\
n=101\end{array}$ \\
\hline
\end{tabular}

*The degree of labelling is an estimate of the percentage of total metaphase chromosome surface area stained positive for BrdUrd. See text for additional details.

(data not shown). If the induction of breaks is random with respect to pre- and post-replication areas, then the repair process must be the same throughout the chromatin.

\subsection{DNA double-strand breaks and repair}

In order to measure DNA damage and repair throughout the cell cycle, cultures were labeled with ${ }^{14}$ C-thymidine before they reached confluency and were then synchronized by different combinations of release to low den sity, aphidicolin block at $\mathrm{G}_{1} / \mathrm{S}$, cell cycle progression, and centrifugal elutriation, as described. Briefly, mitotic cells were collected by shake-off techniques, $\mathrm{G}_{1}$ and $\mathrm{G}_{2}$ cells were purified by elutriation of cultures incubated for $8 \mathrm{~h}$ after release from an aphidicolin block, and $S$ phase

Table 2. Average cell cycle distributions of the synchronized cell populations used for DNA damage and repair, and survival assays

\begin{tabular}{lcccc}
\hline \multicolumn{5}{c}{ Cell cycle distribution $(\%) *$} \\
\hline Cycle phase & $\mathrm{G}_{1}$ & $\mathrm{~S}$ & $\mathrm{G}_{2}$ & $\mathrm{M}$ \\
\hline $\mathrm{G} 1$ & 81 & 15 & 4 & 0 \\
$($ range) & $(69-90)$ & $(8-31)$ & & \\
$\mathrm{S}$ & 2 & 62 & 36 & 0 \\
& $(1-3)$ & $(49-80)$ & $(17-45)$ & \\
$\mathrm{G}_{2}$ & 1 & 28 & 67 & 4 \\
& \multicolumn{5}{c}{$(27-33)$} & $(64-73)$ & $(2-6)$ \\
Mitotic & $10 \dagger$ & $51 \ddagger$ \\
& \multicolumn{5}{c}{$(9-10)$} \\
\hline
\end{tabular}

*Determined by multi-parameter flow cytometry as described in the Materials and methods, except for the mitotic cell fraction.

†Determined from BrdUrd labelling index on cytology preparations.

$\Varangle$ Determined from mitotic index on cytology preparations. cells were obtained by incubating cultures for $4 \mathrm{~h}$ after aphidicolin release. The cell cycle distribution of each fraction was determined by dual parameter flow cytometry, measuring both DNA and BrdUrd incorporation; BrdUrd labelling is essential for accurately determining the position of cells that are at the beginning and end of $\mathrm{S}$ phase (Dutrillaux et al. 1991, Bussink et al. 1995). Table 2 shows the cell cycle distributions of separate preparations of $G_{1}, S, G_{2}$, and $M$ phase cells used for DNA damage analysis and cell survival measurements. Each purified population was irradiated with a total dose of $40 \mathrm{~Gy}$ and the repair of DNA double-strand breaks (dsb) was determined by pulsed-field gel electrophoresis. Table 3 shows that the amount of initial damage was similar in $G_{1}, G_{2}$, and $M$ phase enriched cultures. S phase cells appeared to have sustained less initial damage, although the differences are not significant due to the degree of variation in repeated measurements with $\mathrm{S}$ phase cultures. Figure 4 shows that repair kinetics in $G_{1}, G_{2}$, and $S$ phase cells is the same. Even though the cells were somewhat heterogeneous in their cell cycle distribution (Table 2), the various fractions were enriched enough to conclude that $\mathrm{G}_{2}$ cells repair DNA double-strand breaks. The purified

Table 3. Initial DNA damage induced by $40 \mathrm{~Gy}$ as determined by the percentage of total DNA migrating from the plug during electrophoresis

\begin{tabular}{lcccc}
\hline \multirow{2}{*}{$\begin{array}{l}\text { Initial } \\
\text { damage }\end{array}$} & $\mathrm{G}_{1}$ & $\mathrm{~S}$ & $\mathrm{G}_{2}$ & $\mathrm{M}$ \\
\cline { 2 - 5 } Purified fraction \\
\hline Mean $(\%)$ & $50 \cdot 0$ & $37 \cdot 8$ & $52 \cdot 3$ & $55 \cdot 4$ \\
Range & $45 \cdot 0-56 \cdot 1$ & $30 \cdot 0-42 \cdot 5$ & $47 \cdot 3-60 \cdot 0$ & $54 \cdot 7-56 \cdot 0$ \\
SEM & $3 \cdot 3$ & $3 \cdot 9$ & $3 \cdot 9$ & $0 \cdot 65$ \\
CV $(\%)$ & $11 \cdot 3$ & $17 \cdot 9$ & $13 \cdot 0$ & $1 \cdot 7$ \\
\hline
\end{tabular}




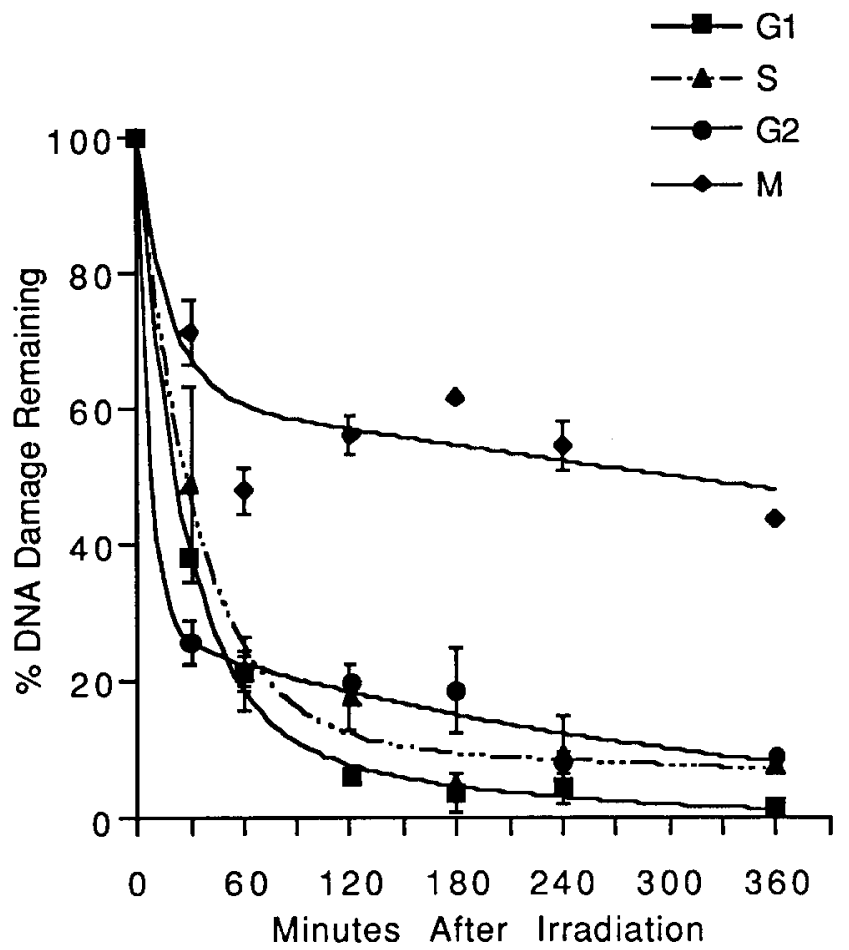

Figure 4. DNA double-strand breaks and repair in synchronized CHO cells in various phases of the cell cycle, determined by pulsed-field gel electrophoresis.

$\mathrm{G}_{2}$ fraction contained an average of $67 \% \mathrm{G}_{2}$ cells (Table 2) and it shows the same rate of repair as $\mathrm{S}$ phase and $G_{1}$ phase cells. We, therefore, conclude that $G_{2}$ phase cells must account for at least part of the DNA repair in that fraction. Whether or not $\mathrm{G}_{2}$ cells repair DNA damage at the same or a slower rate than cells in other phases of the cycle cannot be determined from these experiments. Only mitotic cells appeared different from the other cell cycle phases, since only 40$50 \%$ of their initial damage was repaired, likely related to their state of chromosome condensation.

\subsection{Clonogenic survival measurements}

Cell survival curves were generated for the same populations used for DNA damage and repair measurements and the results are shown in Figure 5. As expected, $\mathrm{S}$ phase was the most radioresistant, while $G_{1}$ and $G_{2}$ phase cells were more sensitive and not significantly different from each other. Again, the purity of the $\mathrm{G}_{2}$ fraction ranged from 60 to $70 \%$, compared with $80-90 \%$ for $\mathrm{G}_{1}$, but the purity is adequate to demonstrate that $\mathrm{G}_{1}$ and $G_{2}$ cells are not drastically different in radio-

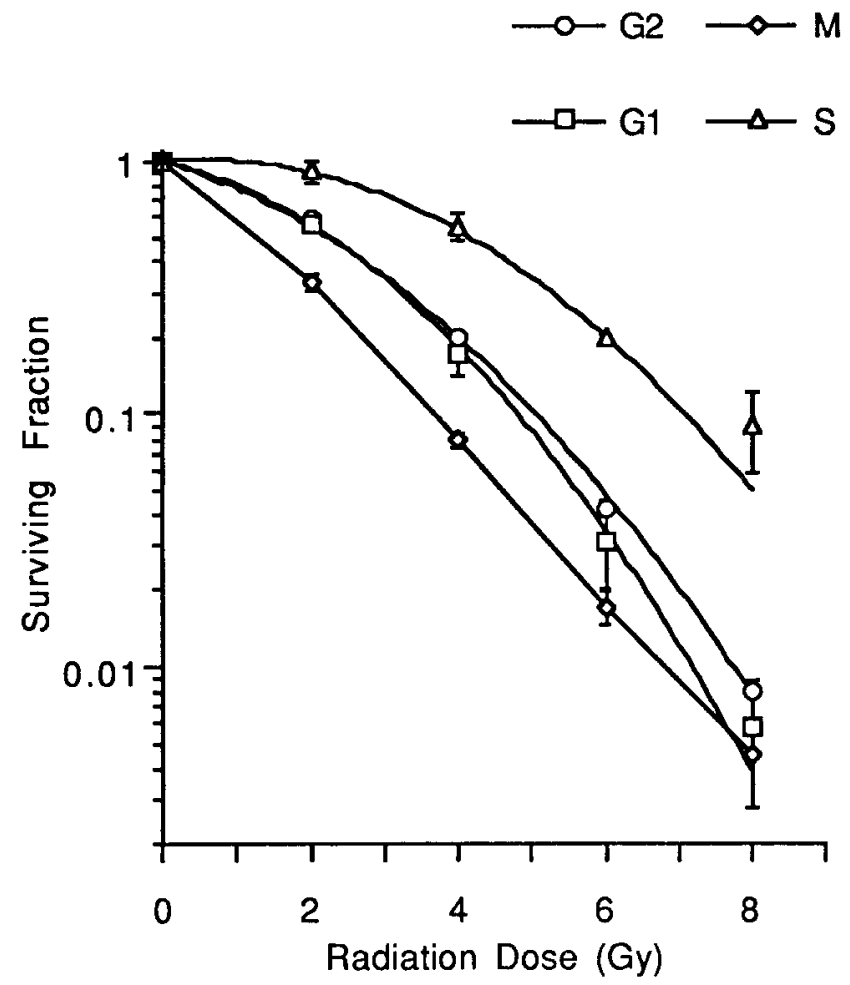

Figure 5. Clonogenic survival of irradiated synchronized CHO cells in various phases of the cell cycle. $\triangle, S$ phase; $O, \mathrm{G}_{2}$ phase; $\square, \mathrm{G}_{1}$ phase; $\diamond, \mathrm{M}$ phase.

sen sitivity. Mitotic cells were the most sen sitive with log-linear survival curves.

\section{Discussion}

The results of this study show that correlations between different parameters of radiosensitivity in Chinese hamster cells is dependent upon the phase of the cell cycle in which they were measured. The relative degrees of chromosome and DNA break induction and repair, as well as clonogenic cell survival, change throughout the cell cycle, thus emphasizing that non-clonogenic endpoints of radiation sensitivity must be used with caution. The most dramatic differences were observed in $S$ and $G_{2}$ phase cells. While chromosome breaks are efficiently repaired in $\mathrm{S}$, there is no repair of them in $G_{2}$, even though DNA breaks are repaired in both phases of the cell cycle. Since it is commonly assumed that both DNA strand breaks and chromosome breaks are related mechanisms and that both contribute to cell lethality, the differences in these parameters were carefully studied in the $S$ and $G_{9}$ phases. 
The data in Figure 1 suggest that the repair of chromosome damage in $\mathrm{G}_{2}$ is very slow or delayed for the first $2 \mathrm{~h}$ after irradiation and then rapid repair begins. This raised the possibility of a radiation induced repair mechanism, which has been suggested by others (Shadley and Wolff 1987, Wolff et al. 1988, Joiner et al. 1993). This observation led to a more complete analysis of chromosome break repair in $S$ and $G_{2}$ phase cells. However, by using BrdUrd to differentiate between mitoses irradiated in $\mathrm{S}$ versus $\mathrm{G}_{2}$ (Figure 2 ), it was determined that the apparent rapid repair after $2 \mathrm{~h}$ was due to the mitotic accumulation of cells that had been treated in S phase. The results, therefore, unequivocally demonstrate that chromatid breaks are not repaired during any part of $\mathrm{G}_{2}$ and that there is no evidence for a radiation induced repair mechanism. In addition, the BrdUrd staining technique allowed us to carefully examine changes in chromatid break repair as cells progress through the $\mathrm{S} / \mathrm{G}_{2}$ border. Metaphases with minimal BrdUrd staining had been irradiated at the very end of $S$ phase and they had fewer breaks remaining at the initial time point $(90 \mathrm{~min})$ than did $\mathrm{G}_{2}$ cells (no BrdUrd labelling), but the flatness of that curve indicates that no additional repair took place as those cells traversed $\mathrm{G}_{2}$. It, therefore, appears that some repair occurred during the final few minutes or seconds of $\mathrm{S}$ phase, but the moment $\mathrm{S}$ phase was completed, repair ended. The cessation of repair is so abrupt that it suggests the possibility of some type of control mechanism. However, there are no additional data to support this notion.

A lack of repair in $\mathrm{G}_{2}$ has not been previously reported for this cell line, possibly because the typically short duration of $\mathrm{G}_{2}$ makes it difficult to differentiate between repair that takes place in $S$ versus $G_{2}$ phase unless $S$ phase cells are labelled. Hittelman and Pollard (1982) used the technique of premature chromosome condensation (PCC) to examine the repair of radiation induced breaks and gaps in this same cell strain (AA8). They reported that the number of PCC breaks and gaps remains constant for $30 \mathrm{~min}$ following irradiation, and that is followed by rapid repair. Those results are consistent with our findings except for the timing (30 versus $90 \mathrm{~min}$ ), but that can be explained by technical differences. Unlike metaphase analysis of chromosome damage, the PCC method is not dependent upon cell cycle progression for visualization of damage. A $\mathrm{G}_{2}$-PCC preparation is, therefore, composed of cells from all parts of $G_{2}$, early to late, while a metaphase preparation is a sequential analysis of chromosomes that become visible as the cells progress to metaphase after treatment. Thus, at early times after irradiation, metaphases represent cells that were treated in late $G_{2}$, while cells treated in $S$ phase do not reach metaphase for at least $90 \mathrm{~min}$. On the other hand, $\mathrm{G}_{2}$ PCC spreads will contain increasing numbers of cells irradiated in $\mathrm{S}$ phase shortly after treatment and become significant within $30 \mathrm{~min}$. This appears to account for the kinetic differences in the results, but both observations are consistent with no $\mathrm{G}_{2}$ repair.

One consequence of no repair in $\mathrm{G}_{2}$ would be an expectation of a simple exponential survival curve for purified $\mathrm{G}_{2}$ cells, similar to that displayed by mitotic cells. Instead, a shouldered survival curve, almost identical to the survival of $G_{1}$ cells, was observed. This questions the validity of interpreting shouldered curves as always being due to the repair of radiation injury. However, it is possible that contamination of the purified $G_{2}$ cells with $S$ phase cells could be responsible for the shape of the initial slope of the $G_{2}$ survival curve. Another potential consequence is related to the phenomenon of radiation induced cell cycle arrest, which can be inferred in these experiments from the delay in the appearance of irradiated BrdUrd labeled cells at metaphase relative to controls. $G_{2}$ arrest is thought to provide time for repair of DNA and chromosome damage before a cell enters mitosis (Darroudi and Natarajan 1987, Utsumi and Elkind 1991) and would be expected to increase cell survival. Support for this notion comes from reports that CHO cell killing is enhanced if the $G_{2}$ delay is abrogated by caffeine treatment (Darroudi and Natarajan 1987, Rowley 1992). How $\mathrm{G}_{2}$ delay contributes to increased survival in cells that do not repair chromatid damage in $\mathrm{G}_{2}$ is not clear.

A dissociation between DNA strand break repair and chromosome break repair was observed during $G_{2}$ phase. Although the $G_{2}$ populations in the DNA repair experiments were contaminated with some cells from other phases, it is clear that $\mathrm{G}_{2}$ cells repair DNA breaks, because it is highly unlikely that the cells from other phases of the cycle could account for the high level of DNA repair observed in that fraction. It is also clear that the repair DNA breaks in $\mathrm{G}_{2}$ does not translate into an ability to repair chromatid breaks. Using a similar cell strain (CHO 10B), Metzger and Iliakis (Metzger and Iliakis 1991) also found no relationship between radiation induced DNA double-strand break repair or PCC repair and cell survival. Similarly, Smeets et al. (1993) failed to find a correlation between cell survival and DNA 
double-strand breaks in human tumour cells. On the other hand, other authors have found a correlation between the rate of DNA double-strand break repair and clonogenic survival (Schwartz et al. 1988, Giaccia et al. 1992). It is logical to assume that DNA strand break repair and chromatid break repair are important for cell survival following irradiation, but a more complete understanding of the mechanisms of those relationships and the exact parameters that should be measured is needed.

In conclusion, the relationship between radiation induced chromatid break repair and DNA break repair changes throughout the cell cycle but not always as would be predicted from changes in radiosensitivity. Although examples of significant correlations between combinations of these endpoints and cell survival have been found for different phases of the cell cycle and for different cell lines, their use is limited.

\section{Acknowledgments}

This work was supported by a fellowship to J. Bussink from the Dutch Cancer Society and research grants CA-50192, CA-50207, and CA-06294 from the National Institutes of Health.

\section{References}

Bill, C. A., Garrett, K. C., Harrell, R., and Tofilon, P. J., 1992, Enhancement of radiation-induced cell killing and DNA double-strand breaks in a human tumor cell line using nanomolar concentrations of Aclacinomycin A. Radiation Research, 129, 315-321.

Blocher, D., Sigut, D., and Hannan, M. A., 1991, Fibroblasts from ataxia telangiectasia (AT) and AT heterozygotes show an enhanced level of residual DNA double-strand breaks after low dose-rate $\gamma$-irradiation as assayed by pulsed field gel elecrophoresis. International Journal of Radiation Biology, 60, 791-802.

Bussink, J., Terry, N. H. A., and Brock, W. A., 1995, Cell cycle analysis of synchronized Chinese hamster cells using bromodeoxyuridine labeling and flow cytometry. In Vitro Cellular and Developmental Biology, 31, 547-552.

Carrano, A. V., 1973, Chromosome aberrations and radiationinduced cell death. II. Predicted and observed cell survival. Mutation Research, 17, 355-366.

Cassoni, A. M., McMillan, T. J., Peacock, J. H., and Steel, G. G., 1992, Differences in the level of DNA double-strand breaks in human tumor cells lines following low doserate irradiation. European Journal of Cancer, 28A, 16101614.

Darroudi, F., and Natarajan, A. T., 1987, Cytological characterization of Chinese hamster ovary X-ray-sensitive mutant cells xrs-5 and xrs-6: I. Induction of chromo- somal aberrations by X-irradiation and its modulation with 3-aminobenzamide and caffeine. Mutation Research, 177, 133-148.

Dewey, W. C., Miller, H. H., and Leeper, D. B., 1971, Chromosomal aberrations and mortality of X-irradiated mammalian cells: Emphasis on repair. Proceedings of the National Academy of Sciences, USA, 68, 667-671.

Dutrillaux, B., Gerbault-Seureau, M., Zafrani, B., and Prieur, M., 1991, Prolonged G2 phase of breast cancer cells and chromosome damage. European Journal of Cancer, 27, 1307-1312.

Elkind, M. M., 1985, DNA damage and cell killing: cause and effect? Cancer, 56, 2351-2363.

Fisher, D. E., 1994, Apoptosis in cancer therapy: crossing the th reshold. Cell, 78, 539-542.

Giaccia, A. J., Schwartz, J., Shieh, J., and Brown, J. M., 1992, The use of asymmetric-field inversion gel electrophoresis to predict tumor cell radiosensitivity. Radiotherapy and Oncology, 24, 231-238.

Hittelman, W. N., and Pollard, M., 1982, A comparison of the DNA and chromosome repair kinetics after gamma irradiation. Radiation Research, 92, 497-509.

Iliakis, G., Pantelias, G. E., and Seaner, R., 1988, Effect of arabinofuranosyladenine on radiation-induced chromosome damage in plateau-phase CHO cells measured by premature chromosome condensation: implications for repair and fixation of $\alpha$-PLD. Radiation Research, 114, 361-378.

Jayanth, R. V., and Hittelman, W. N., 1991, 9- $\beta$-D-Arabinofuranosyl-2-fluoroadenine (F-ara-A) inhibits both the fast and slow components of chromosome repair. In Radiation Research: A Twentieth-Century Perspective, vol. 1, edited by J. D. Chapman, W. C. Dewey and G. F. Whitmore (San Francisco: Academic), p. 411.

Joiner, M. C., Marples, B., and Johns, H., 1993, The response of tissues to very low doses per fraction: a reflection of induced repair? In Acute and Long-Term Side-Effects of Radiotherapy. Biological Basis and Clinical Relevance, edited by W. Hinkelbein (Berlin: Springer), vol. 130, pp. 27-40.

Joshi, G. P., Nelson, W. J., Revell, S. H., and Shaw, C. A., 1982, $\mathrm{X}$-ray induced chromosome damage in live mammalian cells, and improved measurements of its effects on their colony-forming ability. International Journal of Radiation Biology, 41, 161-181.

Kelland, L. R., Burgess, L., and Steel, G. G., 1987, Characterization of four new cell lines derived from human squamous carcinomas of the uterine cervix. Cancer Research, 47, 4947-4952.

Kelland, L. R., Edwards, S. M., and Steel, G. G., 1988, Induction and rejoining of DNA double-strand breaks in human cervix carcinoma cell lines of differing radiosensitivity. Radiation Research, 116, 526-538.

McIlwrath, A. J., Vasey, P. A., Ross, G. M., and Brown, R., 1994, Cell cycle arrests and radiosensitivity of human tumor cell lines: dependence on wild-type p53 for radiosensitivity. Cancer Research, 54, 3718-3722.

Meistrich, M. L., 1977, Separation of spermatogenic cells and nuclei from rodent testes. In Methods in Cell Biology, vol. 15, edited by D. M. Prescott (New York: Academic), p. 15.

Meistrich, M. L., Meyn, R. E., and Bargogie, B., 1977, Synchronization of mouse L-P 59 cells by centrifugal elutriation separation. Experimental Cell Research, 105, 169-177.

Metzger, M. L., and Iliakis, G., 1991, Kinetics of DNA double- 
strand break repair throughout the cell cycle as assayed by pulsed-field gel electrophoresis in CHO cells. International Journal of Radiation Biology, 59, 1325-1339.

Midander, J., and Revesz, L., 1980, The frequency of micronuclei as a measure of cell survival in irradiated cell populations. International Journal of Radiation Biology, 38, 237-242.

RADFORD, R. R., 1991, Mouse lymphoma cells that undergo in terphase dealth show markedly increased sensitivity to radiation-induced DNA double-strand breakage as compared with cells that undergo mitotic death. International Journal of Radiation Biology, 59, 13531369.

Rowley, R., 1992, Reduction of radiation-induced $\mathrm{G}_{2}$ arrest by caffeine. Radiation Research, 129, 224-227.

Schwartz, J. L., Rotmensch, J., Giovanazzi, S., Cohen, M. B., and Weichselbaum, R. R., 1988, Faster repair of DNA double-strand breaks in radioresistant human tumor cells. International Journal of Radiation Oncology, Biology, Physics, 15, 907-912.

Shadley, J. D., and WolfF, S., 1987, Very low doses of X-rays can cause human lymphocytes to become less susceptible to ionizing radiation. Mutagenesis, 2, 95-96.

Smeets, M. F. M. A., Mooren, E. H. M., and BegG, A. C., 1993, Radiation-induced DNA damage and repair in radiosensitive and radioresistant human tumour cells measured by field inversion gel electrophoresis. International Journal of Radiation Biology, 63, 703-713.

Su, L.-N., and Little, J. B., 1993, Prolonged cell cycle delay in radioresistant human cell lines transfected with activated ras oncogene and/or Simian virus 40 T-antigen. Radiation Research, 133, 73-79.

Terry, N. H. A., White, R. A., Meistrich, M. L., and Calkins, D. P., 1991, Evaluation of flow cytometric methods for determining population potential doubling times using cultured cells. Cytometry, 12, 234-241.

Utsumi, H., and Elkind, M. M., 1991, Caffeine and $\mathrm{D}_{2} \mathrm{O}$ medium interact in affecting the expresion of radiation-induced potentially lethal damage. International Journal of Radiation Biology, 60, 647-655.

WARD, J. F., 1986, Mechanisms of DNA repair and their potential modification for radiotherapy. International Journal of Radiation Oncology, Biology, Physics, 12, 10271032.

Wolff, S., Afzal, V., Wiencke, J. K., Olivieri, G., and Michaeli, A., 1988, Human lymphocytes exposed to low doses of ionizing radiations become refractory to high doses of radiation as well as to chemical mutagens that induce double-strand breaks in DNA. International Journal of Radiation Biology, 53, 39-48. 